\title{
PRACTICAL CONSIDERATIONS OF GREEDY COMPRESSED SAMPLING METHODS APPLICATION FOR OFDM CHANNEL ESTIMATION
}

Kotlyarov V. V. - Post-graduate student of Department of Radio Engineering Devices and Systems of National echnical university of Ukraine "Igor Sikorsky Kyiv polytechnic institute", Kyiv, Ukraine.

Shpylka A. A. - PhD, Associated Professor of Department of Radio Engineering Devices and Systems of National technical university of Ukraine "Igor Sikorsky Kyiv polytechnic institute", Kyiv, Ukraine.

\section{ABSTRACT}

Context. Traditionally a large number of pilot carriers are utilized to acquire channel state information in OFDM based systems. A larger number of pilot carriers gives better channel state estimation but leads to lower spectrum efficiency of the system.

Objective. Primary objective of this paper is to look at the practical aspects of the application of novel CS-based channel estimation technique, that can achieve estimation quality on reduced training data, in context of real pilot aided OFDM systems.

Method. A novel technique CS enables representation of sparse signals using fewer samples as compared to its original size. Exploiting the sparse nature of channel impulse response of multipath channels, we apply the CS technique for channel estimation in pilot aided OFDM system based on ISDB-T standard.

Results. In this paper, we consider two the most popular CS-based recovery algorithms - OMP and CoSaMP. The MSE performance metrics are given for both CS-based channel estimation algorithms. Simulations results demonstrate that CoSaMP provides more stable results while requires more pilot carriers than OMP to achieve good estimation quality. Both algorithms require a priori knowledge of channel sparsity level but CoSaMP is much more sensitive to a correctness of this information.

Conclusions. The compressed sampling approach shows the impressive capability of channel impulse response recovery from a significantly smaller amount of pilot carriers than traditional linear methods require. However, the need of sparsity knowledge by the most popular CS recovery methods seriously limits the applicability of these algorithms in real OFDM receivers. Nevertheless, CSbased channel estimation is a promising technique which worth further investigation to overcome this limitation.

KEYWORDS: OFDM, multipath channel, channel estimation, compressed sampling.

\author{
ABBREVIATIONS \\ OFDM - orthogonal frequency division multiplexing; \\ LS - least squares; \\ ML - maximum likelihood; \\ CS - compressed sampling; \\ OMP - orthogonal matching pursuit; \\ CoSaMP - compressive sampling matching pursuit; \\ MSE - mean square error; \\ CNR - carrier to noise ratio; \\ FFT - fast Fourier transform;
}

ISDB-T - integrated services digital broadcastingterrestrial;

SFN - single frequency network;

ADC - analog to digital converter;

$\mathrm{SP}$ - scatter pilots;

TMCC - transmission and multiplexing configuration control.

\section{NOMENCLATURE}

$\Phi \in C^{M \times N}$ - sampling matrix;

$H \in C^{N}$ - channel frequency response;

$h \in C^{N}$ - channel impulse response;

$\tau_{i}$ - delay of $i$-th distinguishable channel tap;

$K$ - channel sparsity;

$N$ - number of carriers in one OFDM symbol;

$w$ - white Gaussian noise with unknown statistics $\sigma^{2}$

$X \in C^{N \times N}-$ transmitted carriers in one OFDM symbol;

(C) Kotlyarov V. V., Shpylka A. A., 2018

DOI 10.15588/1607-3274-2018-4-16
$Y \in C^{N}$ - received carriers in one OFDM symbol;

$N_{P}$ - number of pilot carriers in one OFDM symbol;

$\hat{\Phi} \in C^{N_{P} \times N}$ - partial DFT sampling matrix for pilot carriers;

$X_{P} \in C^{N_{P}}$ - transmitter pilot carriers in one OFDM symbol;

$Y_{P} \in C^{N_{P}}$ - received pilot carriers in one OFDM symbol;

$\widetilde{h} \in C^{N}$ - estimated / recovered channel impulse response.

\section{INTRODUCTION}

OFDM is the most popular modulation technique widely applied in modern wireless communication systems. Channel estimation is an integral part of high data rate wireless communication systems. It is essentially a process of recovery of channel state information, which is required for data decoding. The accuracy of channel estimation has great importance for high data rate decoding and is one of the key challenges in OFDM based wireless communication systems.

Most of the OFDM based systems employ pilot subcarriers for channel estimation. Traditional linear channel estimation techniques [1-5], like the ML and LS, require a large number of pilots to achieve a proper accuracy of channel state information recovery. A higher number of pilots, that do not carry data, seriously reduce spectral utilization efficiency of the system. 
But these traditional methods do not exploit the fact that the impulse response of the wireless channels is often sparse [6]. Sparse channel means there are a few strong distinguishable signal paths in it due to reflection, refraction, and scattering of the signal on its way from the transmitter to the receiver. Channel estimation method that uses the advantage of the channel sparsity allows reduction of the number of pilot carriers per OFDM symbol and in such way improves the efficiency of channel bandwidth utilization. It also achieves higher channel estimation accuracy in mobile reception scenario compared to traditional methods. The methods best suited for sparse channel estimation are developed in CS theory.

CS [7] is a novel signal processing technique that postulates that any signal that can be sparsely represented in some orthogonal space can be sampled with lower frequency and accurately reconstructed with much fewer samples than specified by classic sampling theory by Nyquist $[8,9]$. In the theory of CS, a sampling is a linear operator applied to a $k$-sparse signal. The process of collecting multiple samples is viewed as the action of a sampling matrix $\Phi$ on the target signal. For $M$ compressed measurements of a signal in $C^{N}$ the sampling matrix has dimensions $M \times N$. Since sampling matrix $\Phi^{M \times N}$ must not map two different $k$-sparse signals to the same set of compressed measurements, the minimum number of measurements is $M \geq 2 k$. Moreover each collection of $2 k$ columns of $\Phi^{M \times N}$ must be nonsingular.

\section{PROBLEM STATEMENT}

For wireless communications, the transmission medium is the radio channel between transmitter and receiver. The signal can get from the transmitter to the receiver via a number of different propagation paths. Each of the paths has distinct amplitude, propagation time, departure and arrival directions. Because of this, the signal at the receiver side consists of the sum of several components with different energy and phase shits to each other and noise. Different phase shifts of signal components lead to interference, which creates so-called frequency selective fading - the effect of significant amplitude changes of frequency components in the signal.

Consider the frequency selective fading channel in OFDM system, whose coherence time is much larger than the symbol period. If ADC sampling frequency is $F_{s}$, its discrete sample-time channel model is:

$$
h[t]=\sum_{i=1}^{K} a_{i} \delta\left(t-\tau_{i} F s\right),
$$

where $K$ is the number of dominant transmit paths, $a_{i}$ is the complex amplitude and $\tau_{i}$ is the delay of $i$-th distinguishable channel tap. When there are just a few none zero elements in $h=\left[0, a_{1}, a_{2}, 0, \ldots, a_{K}, \ldots, 0,0,0\right] \in C^{N}$, we say that such channel is $K$ sparse.

(C) Kotlyarov V. V., Shpylka A. A., 2018

DOI 10.15588/1607-3274-2018-4-16

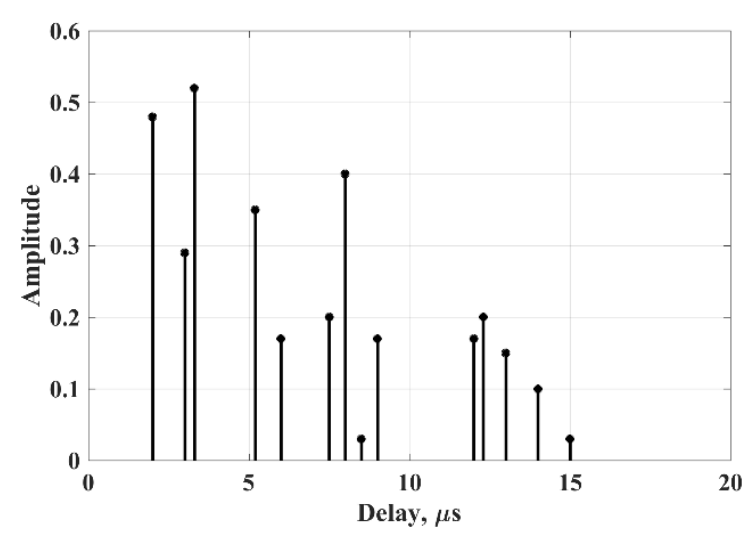

Figure 1 - The sparse impulse response of the multipath channel

The frequency response of the channel model (1) is $H=\Phi h$, where $\Phi \in C^{N \times N}$ is Fourier matrix.

Provided that in the OFDM system, the total number of subcarriers is $N$, among them the number of pilot subcarriers is $N_{P} \ll N$. Carriers $x_{i}$ contain data and pilot signals in one OFDM symbol. Cyclic prefix length $T_{g}<\tau_{K}$ is greater than the maximum possible path delay in every OFDM symbol. The frequency domain signal at the receiver is a vector $Y \in C^{N}$, which can be written as:

$$
Y=X H+w,
$$

where $X=\operatorname{diag}\left(x_{1}, x_{2}, \ldots, x_{N}\right)$ is $C^{N \times N}$ matrix with carriers, $H \in C^{N}$ is a vector of complex amplitudes of channel frequency response, $w$ is white Gaussian noise term with unknown statistics $\sigma^{2}$.

Since $H=\Phi h,(2)$ can be equivalently rewritten to:

$$
Y=X \Phi h+w
$$

where $h=\left[0, a_{1}, a_{2}, 0, \ldots, a_{K}, \ldots, 0,0,0\right]^{T} \in C^{N} \quad$ is $\quad$ sparse multipath channel impulse response with only $K \ll N$ nonzero entries and $\Phi \in C^{N \times N}$ is Fourier matrix.

At the OFDM receiver side, $h$ and $w$ are fully unknown. $Y$ and $X$ are partially known for only pilot carriers $X_{P}$ and $Y_{P}$, where the number of pilot carriers $N_{P} \ll N$ significantly less than a total number of carriers in the OFDM symbol. In channel estimation context model (3) for receiver side transforms to:

$$
Y_{P}=X_{P} \hat{\Phi} h+w
$$

where $P=\left[p_{1}, p_{2}, \ldots, p_{N_{P}}\right] \in Z$, is pilot positions in the OFDM symbol and $\hat{\Phi} \in C^{N_{P} \times N}$, is matrix derived from Fourier matrix in a next way:

$$
\hat{\Phi}=\frac{1}{\sqrt{N}}\left(\begin{array}{ccc}
\omega_{P_{1}, 0} & \ldots & \omega_{P_{1}, N-1} \\
\vdots & \ddots & \vdots \\
\omega_{P_{N_{P}}, 0} & \ldots & \omega_{P_{N_{P}}, N-1}
\end{array}\right)
$$$$
\text { where } \omega_{m, n}=e^{-2 \pi j \frac{m \cdot n}{N}} \text {. }
$$ 
The channel estimation process is essentially a recovery of the original high dimensional $h \in C^{N}$ from low dimensional $X_{P} \in C^{N_{P}}$ and $Y_{P} \in C^{N_{P}}$ available at the receiver side.

\section{REVIEW OF THE LITERATURE}

The most common channel estimation techniques in the literature for OFDM systems use repeated blocks of pilots or training data to formulate ML or LS estimation algorithms. Both of the methods based on wellestablished theory [1-5] and provide identical channel estimation results. To perform LS estimations, we need to formulate an overdetermined system of linear equations in terms of the parameters to be estimated [4]. To perform ML parameter estimations, we need first to form a loglikelihood function in terms of the parameters to be estimated [5].

According to the theory the only way to improve estimation quality of ML and LS estimators is to increase the number of training data in the system. But more training data means reduction of data throughput in the system. Moreover, the use of repeated OFDM training blocks requires that channel fading remains unchanged at least over the period of the repeated blocks. This implies that the maximum Doppler frequency must satisfy $f_{D}<1 / T$, where $f_{D}=v f_{c} / c, c$ is the speed of light, $T$ is one complete OFDM block time length in seconds, and $f_{c}$ is the carrier frequency in $\mathrm{Hz}$. Corresponding maximum mobile receiver speed in this case is $v<\frac{c}{f_{c} T}$.

From the last formula it's clear that to increase mobility of the reception we need to reduce training block time length. In the best case we'd like to be able to estimate channel state information for every OFDM symbol independently. But according to the ML and LS theory this will inevitably degrade estimation quality of these classical methods [1-5]. This contradiction between channel estimation quality, data throughput and reception mobility of classical channel estimation methods force researchers to look for new techniques that can achieve estimation quality on reduced training data.

Compared with classical channel estimation methods, CS [7] reconstruction methods exploit the fact of the channel sparsity, which can effectively balance the channel estimation performance spectral efficiency and computational complexity. Different CS reconstruction algorithms may have different channel estimation performance. Majority of CS reconstruction methods are based on two types $-l_{1}$ norm minimization methods [10]. The second type is greedy pursuit algorithms [11], such as OMP and CoSaMP. Greedy algorithms are more popular because of its lower computation complexity [12]. In the early stages, OMP algorithm was employed to estimate sparse channel with improved estimation performance [13]. Recently, CoSaMP algorithm gradually replaces OMP to realize more effective sparse channel estimation [14] in OFDM system.
While currently available works are mainly aimed to proof the ability of CS to recover channel state information of sparse channels, the primary objective of this paper is to look at the practical aspects of application of CS-based channel estimation methods in real pilot aided OFDM systems.

\section{MATERIALS AND METHODS}

The channel estimation process is a recovery of the original high dimensional $h \in C^{N}$ from low dimensional $X_{P} \in C^{N_{P}}$ and $Y_{P} \in C^{N_{P}}$ available at the receiver side. Since known part of the considered mathematical model (4) is significantly less than unknown, due to $N_{P} \ll N$, the recovery of $h \in C^{N}$ is a classical inverse problem addressed in CS theory [7-9]. According to the theory, sparse solution of the undetermined system can be found with high probability via $l_{l}$ norm minimization process. Within CS framework sparse channel estimation problem can be defined in a next way:

$$
\begin{gathered}
\tilde{h}=\arg \min _{h \in C^{N_{P}}}\|h\|_{1}, \\
\text { subjected to }\left\|Y_{P} / X_{P}-\hat{\Phi} h\right\|_{2} \leq \varepsilon
\end{gathered}
$$

where $\varepsilon$ is a predefined noise level proportional to $\sigma^{2}$.

For inverse problem (5) CS theory proposes roughly two categories of recovery algorithms. One category is convex optimization algorithms [10], which guarantee global optimal solution but have high computational complexity. The other category is greedy algorithms, which can give a suboptimal solution but are easy to implement in practice [11-14].

In this paper, we study recovery performance of OMP and CoSaMP-two the most popular greedy algorithms, applied to sparse channel estimation in pilot-aided OFDM systems.

OMP is an iterative algorithm that at every step takes an atom from the orthonormal dictionary with the highest correlation to compressed measurements residue [13]. The algorithm is prohibited from taking the same atom twice and so all resulting components in the recovered signal are orthogonal to each other. This continues until some stopping criteria are met. The most common stopping criteria in all CS greedy algorithms is a number of recovered nonzero components (i.e. sparsity level). Pseudocode for OMP is shown in Algorithm 1.

\footnotetext{
Algorithm 1 OMP

Require: number of channel paths $k$ (sparsity, number of iterations)

Input: sampling matrix $\hat{\Phi} \in C^{N_{P} \times N}$, measurement vector $y \in C^{N_{P}}, y \leftarrow Y_{P} / X_{P}$

1: Initialize: $i \leftarrow 1, \tilde{h}_{0} \leftarrow 0, \lambda_{0} \leftarrow 0, r_{0} \leftarrow y$

2: while $i \leq k$ do
} 
3: $\phi_{i} \leftarrow \arg \max _{1}\left|\hat{\Phi}^{T} r_{i-1}\right|$ ffind 1 atom in $\hat{\Phi}$ with max

correlation to the residue\}

4: $\lambda_{i} \leftarrow \lambda_{i-1} \cup \phi_{i} \quad$ \{add atom position to support $\lambda$ \}

5: $\widetilde{h}_{i} \leftarrow \hat{\Phi}_{\lambda_{i}}^{\dagger} y \quad$ \{re-estimate with new support

6: $r_{i} \leftarrow y-\hat{\Phi} \widetilde{h}_{i} \quad$ \{update the residue

$7: i \leftarrow i+1$

\section{8: end while}

Output: estimated Channel Impulse Response $\widetilde{h}_{k} \in C^{N}$ after $k$ iterations

CoSaMP method [14] is based on OMP idea, but it incorporates several other ideas to accelerate the algorithm and to provide strong reconstruction guarantees that OMP does not provide. Unlike OMP algorithm, CoSaMP identifies $2 k$ orthogonal dictionary atoms at each iteration. This allows CoSaMP algorithm to run faster for many types of signals but requires a priori knowledge of the sparsity level $k$ as part of its input. Pseudocode for CoSaMP is shown in Algorithm 2.

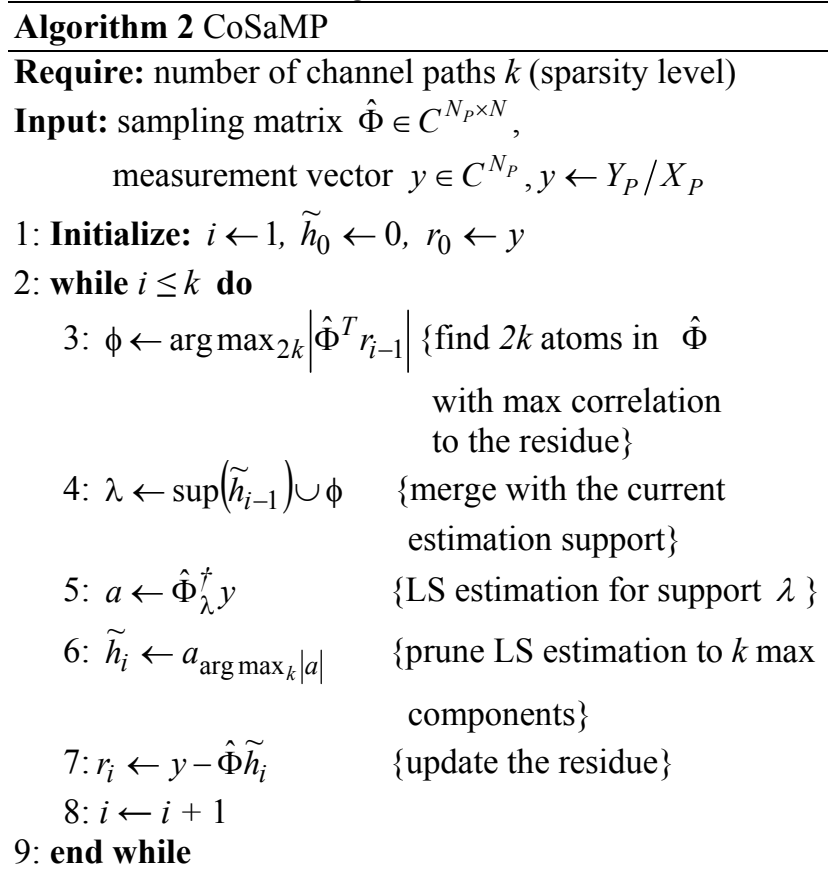

Output: estimated Channel Impulse Response $\widetilde{h}_{k} \in C^{N}$ after $k$ iterations

\section{EXPERIMENTS}

In all the simulation cases the setup is configured according to Mode 1 of ISDB-T standard [15] with FFT size $N=2048$ and the guard interval length of $T_{g}=512$. To reduce the uniformity of sampling, we used SP together with TMCC as pilot carriers. In such way, the maximal number of available pilot carriers in each OFDM symbol is $N_{P}=157$ for Mode 1 in accordance with the standard. For multipath channel model we use two groups of six-tap typical urban channel models [16] with the variable delay between groups (see table 1 for more details). Such multipath channel has $2 \times 6$ dominant taps, which means actual channel sparsity in all the simulation cases is the same and equals 12. Such structure of the channel model allows simulation of typical signal propagation in SFN.

\section{RESULTS}

The simulations are carried out to compare the performance of the two proposed algorithms in different channel conditions and input parameters scenarios. At each simulation step, a recovery of channel impulse response of the particular multipath channel is performed by OMP and CoSaMP from the same input data set for both algorithms. The efficiency of the algorithms is evaluated via the MSE of the channel impulse response recovery by the next formula:

$$
M S E=E\left[\frac{1}{N} \sum_{n=1}^{N}\left(\widetilde{h}_{n}-h_{n}\right)^{2}\right],
$$

where $\tilde{h} \in C^{N}$ is recovered channel impulse response, $h \in C^{N}$ actual channel impulse response, $N$ length of the channel impulse response.

\section{DISCUSSION}

Fig. 2a compares the MSE performance of the two algorithms against CNR. The channel model parameters are according to table 1 . The number of pilot carriers used for impulse response recovery is $N_{P}=157$. It is clear that MSE from both algorithms is decreasing with the CNR increase, but CoSaMP has better recovery performance in low noise conditions than OMP.

Fig. $2 b$ shows the MSE performance of the two algorithms against channel length (max delay spread of the channel). The length of the channel model is defined by the group delay values (see table 1). CNR is fixed at $20 \mathrm{~dB}$. The number of pilot carriers used for impulse response recovery is $N_{P}=157$. Both algorithms show similar recovery performance that does not depend on the channel length. It is noticeable that OMP provides less stable results than CoSaMP. This can be explained by OMP's greedy nature, that does not give reconstruction guarantees.

Fig.2c presents the MSE performance of the two algorithms against the value of sparsity parameter $K$, which should be equal to a number of signal propagation paths in the channel (channel sparsity). Both of the algorithms require this parameter at the input. From the structure of algorithm 1 it is clear that OMP uses paramater $K$ only at step 2 for iteration count, while CoSaMP uses parameter $K$ at steps 2, 3 and 6 for interation count, support assumption update and pruning of the recovered components. Because of that CoSaMP is significantly more sensitive to the correctness of value $K$ and this clearly visible in the result of simulation.

Fig. 2d compares the MSE performance of the two algorithms against a number of pilot carriers $N_{P}$ used for the recovery. All channel model parameters are according to table 1 . CNR is fixed at $20 \mathrm{~dB}$. We observe that CoSaMP requires more pilot carriers to achieve the same recovery performance level as OMP. This is especially noticeable when small number of pilot carriers is used. 
Table 1 - SFN channel model parameters

\begin{tabular}{|c|c|c|c|c|c|c|c|c|c|c|c|c|}
\hline Group & \multicolumn{6}{|c|}{$\mathbf{A}$} & \multicolumn{6}{|c|}{ B } \\
\hline Group delay, $\mu s$ & \multicolumn{6}{|c|}{0} & \multicolumn{6}{|c|}{ typical 80 or varies from 6 to 250} \\
\hline Path № & 1 & 2 & 3 & 4 & 5 & 6 & 7 & 8 & 9 & 10 & 11 & 12 \\
\hline Delay $\tau_{i}, \mu s$ & 0 & 0,2 & 0,5 & 1,6 & 2,3 & 5 & 0 & 0,2 & 0,5 & 1,6 & 2,3 & 5 \\
\hline Total delay, $\mu s$ & 0 & 0,2 & 0,5 & 1,6 & 2,3 & 5 & 80 & 80,2 & 80,5 & 81,6 & 82,3 & 85 \\
\hline Path Loss, $d \mathrm{~B}$ & -3 & 0 & -2 & -6 & -8 & -10 & -9 & -6 & -8 & -12 & -14 & -16 \\
\hline
\end{tabular}

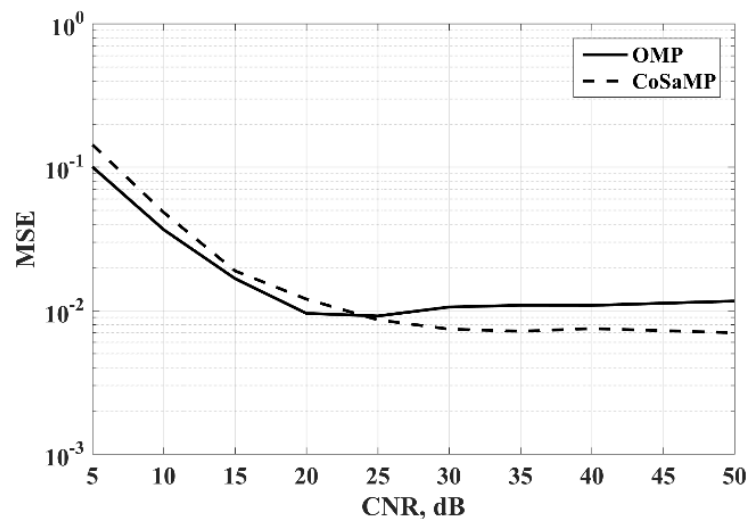

a

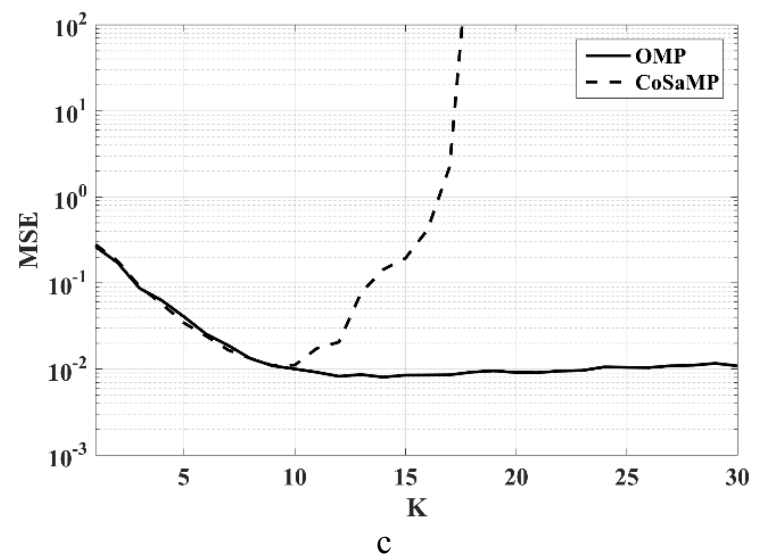

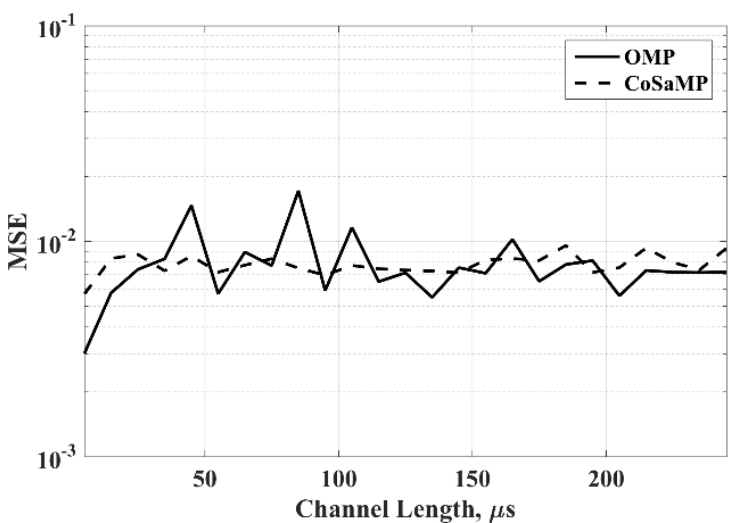

$\mathrm{b}$

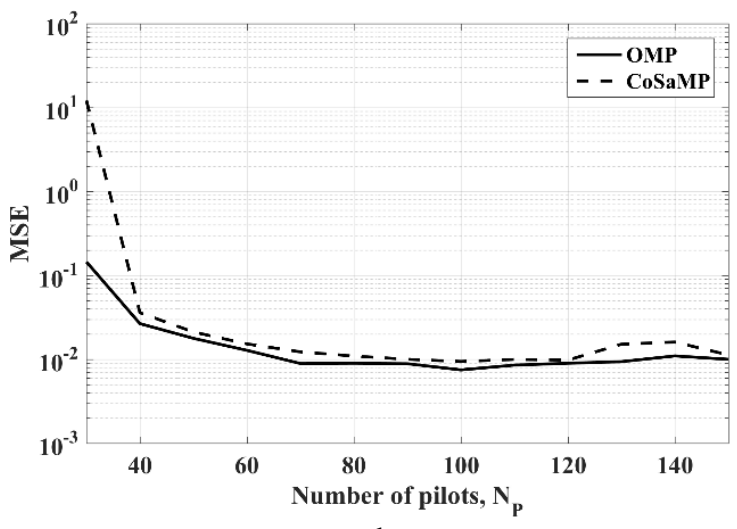

$\mathrm{d}$

Figure 2 - Simulation results of Channel State Information recovery with OMP and CoSaMP algorithms: (a) MSE of the recovery versus CNR, (b) MSE versus channel length, (c) MSE versus sparsity parameter K, (d) MSE versus number of pilots used for recovery

\section{CONCLUSIONS}

In this paper we have provided comparison of two CS algorithms in context of channel impulse response estimation in OFDM based system. Simulation results based on ISDB-T standard shows that OMP algorithms is more sensitive to noise and does not guarantee the recovery performance for every symbol. CoSaMP algorithm requires more pilot carriers than OMP for the same level of recovery performance but provides stable MSE performance of the recovery. Both algorithms require a priori knowledge of channel sparsity but CoSaMP is very sensitive to a correctness of this parameter. Unfortunately, in real life channel sparsity is not known a priori and moreover is not constant over time. This significantly limits applicability of these algorithms in real wireless OFDM receivers. Nevertheless, CS approach shows impressive capability of channel impulse response recovery from significantly smaller amount of pilot carriers than traditional LS based linear methods require. CS-based Channel Estimation is promising technique which worth of further investigation.

\section{REFERENCES}

1. Proakis J. G. Digital communications 4ed. New York, McGraw-Hill, 1983, 1002 p.

2. Van de Beek J-J., Edfors O., Sandell M., et al. On Channel Estimation in OFDM Systems, Vehicular Technology: 45th international conference, Chicago, 25-28 july 1995: proceedings. Chicago, IEEE, 1995, Vol. 2, pp. 815-819. DOI: 10.1109/VETEC.1995.504981

3. Li Y. Pilot-Symbol-Aided Channel Estimation for OFDM in Wireless Systems, IEEE Transactions on Vehicular Technology, 2000, Vol. 49, Issue 4, p. 1207-1215. DOI: $10.1109 / 25.875230$

4. Wang X., Wu Y., Chouinard J. Y. Modified Channel Estimation Algorithms for OFDM Systems with Reduced Complexity, Signal processing: 7 th international conference, Beijing, 31 august - 4 september 2004: proceedings. Beijing, IEEE, 2004, Vol. 2. P. 1747-1751. DOI: 10.1109/ICOSP.2004.1452558 
5. Khan M. Z. Low-Complexity ML Channel Estimation Schemes for OFDM, Conference on networks: 13 th international conference, Kuala Lumpur, 16-18 november 2005: proceedings. Kuala Lumpur, IEEE, 2005, Vol. 2 , pp. 607-612. DOI: 10.1109/ICON.2005.1635572

6. Zhou Y., Herdin M., Sayeed A. M., Bonek E. Experimental study of MIMO channel statistics and capacity via the virtual channel representation [Electronic resource]. Access mode:

https://pdfs.semanticscholar.org/266c/3a3e8228381a9335df 7d868ba5d0d2803c38.pdf

7. Donoho D. L Compressed sensing, IEEE Transactions on Information Theory, 2006, Vol. 52, No. 4, pp. 1289-1306. DOI: $10.1109 /$ TIT.2006.871582

8. Candes E. J., Wakin M. B. An Introduction To Compressive Sampling, IEEE Signal Processing Magazine, 2008, Vol. 25, Issue 2, pp. 21-30. DOI: 10.1109/MSP.2007.914731

9. Baraniuk R. G. Compressive Sensing[Lectures Notes], IEEE Signal Processing Magazine, 2007, Vol. 24, Issue 4, pp. 118-121. DOI: 10.1109/MSP.2007.4286571

10. Berger C. R., Wang Z. H., Huang J. Z. et al. Application of compressive sensing to sparse channel estimation, IEEE Communication Magazine, 2010, Vol. 48, Issue 11, pp. 164 174. DOI: $10.1109 / \mathrm{MCOM} .2010 .5621984$
11. Cotter S. F., Rao B. D. Sparse channel estimation via matching pursuit with application to equalization, IEEE Transaction on Communication, 2002, Vol. 50, Issue 3, pp. 374-377. DOI: 10.1109/26.990897

12. Maechler P., Greisen P., Sporrer B. et al. Implementation of greedy algorithms for LTE sparse channel estimation, Conference Signals, System and Computers: 44th Asilomar Conference, Pacific Grove, 7-10 November 2010: proceedings. Pacific Grove, IEEE, 2010, pp. 400-405. DOI: 10.1109/ACSSC.2010.5757587

13. Tropp J. A., Gilbert A. C. Signal recovery from random measurements via orthogonal matching pursuit, IEEE Transactions of Information Theory, 2007, Vol. 53, Issue 12, pp. 4655-4666. DOI: 10.1109/TIT.2007.909108

14. Needell D., Tropp J. A. CoSaMP: Iterative signal recovery from incomplete and inaccurate samples, Applied and Computational Harmonic Analysis, 2009, Vol. 26, Issue 3, pp. 301-321. DOI: 10.1016/j.acha.2008.07.002

15. Transmission System for Digital Terrestrial Television Broadcast: standard v. 2.2. [Effective from 18 March 2014]. ARIB, 2014, $195 \mathrm{p}$.

16. Universal mobile telecommunications systems; Deployment aspects: technical report: 3GPP TR 25.943 v14.0.0/ ETSI, 2017, 15 p.

Received 11.05.2018 Accepted 25.05.2018

УДК 654.1:004.94

\section{ПРАКТИЧНІ АСПЕКТИ ЗАСТОСУВАННЯ ЖАДІБНИХ МЕТОДІВ РОЗРІДЖЕННОЇ ДИСКРЕТИЗАЦІЇ ДЛЯ ОЦІНКИ ХАРАКТЕРИСТИКИ КАНАЛУ В СИСТЕМАХ 3 ОFDМ}

Котляров В. В. - аспірант кафедри радіотехнічних пристроїв та систем Національного технічного університету України «Київський політехнічний інститут ім. Ігоря Сікорського», Київ, Україна.

Шпилька О. О. - канд. техн. наук, доцент кафедри радіотехнічних пристроїв та систем Національного технічного університету України «Київський політехнічний інститут ім. Ігоря Сікорського», Київ, Україна.

\section{АНОТАЦІЯ}

Актуальність. Для отримання інформації про стан каналу в системах на основі ортогонального частотного поділу (OFDM) традиційно використовується велика кількість пілотних несучих. Збільшення кількості пілотних несучих покращує оцінку стану каналу, але призводить до зниження спектральної ефективності системи.

Мета. Основна мета даної роботи дослідити практичні аспекти застосування техніки розрідженій дискретизації, яка дозволяє оцінювати канальну характеристику по невеликій кількості пілотних несучих, в контексті реальних OFDM систем.

Метод. Сучасна технологія розрідженій дискретизації (CS) пропонує відновлювати сигнали, які мають розріджене подання у деякому базисі, шляхом мінімізації $L$ норми, що дозволяє використовувати меншу кількість вибірок ніж вимагають класичні методи. Використовуючи розріджену природу імпульсної характеристики багатопроменевих каналів, ми застосували техніку розрідженій дискретизації для оцінки каналу в системах OFDM з пілотними несучими на прикладі стандарту ISDB-T.

Результати. В даній роботі порівнюються результати оцінки каналу для двох найпопулярніших алгоритмів відновлення на основі CS-Orthogonal Matching Pursuit (OMP) i Compressive Sampling Matching Pursuit (CoSaMP). Наведено показники середньоквадратичної помилки (MSE) для алгоритмів оцінки каналу на основі CS. Результати моделювання показують, що CoSaMP забезпечує більш стабільні результати, але для отримання хорошої якості оцінки вимагає більше пілотних несучих, ніж OMP. Обидва алгоритми вимагають апріорного знання рівня розрідженості канальної характеристики, але СoSaMP набагато більш чутливий до правильності цієї інформації.

Висновки. Метод розрідженої дискретизації показує вражаючу здатність відновлення імпульсної характеристики каналу по значно меншій кількості пілотних несучих, ніж вимагають традиційні лінійні методи. Однак потреба популярних CS методів відновлення в апріорно знанні рівня розрідженості характеристики суттэво обмежує можливість застосування цих алгоритмів в реальних приймачах OFDM. Проте, оцінка каналу на основі CS є багатообіцяючим методом, який заслуговує подальшого вивчення з метою усунення даного обмеження.

КЛЮЧОВІ СЛОВА: OFDM, багатопроменевий канал, оцінка характеристики каналу, розріджена дискретизація.

УДК 654.1:004.94

\section{ПРАКТИЧЕСКИЕ АСПЕКТЫ ПРИМЕНЕНИЯ ЖАДНЫХ МЕТОДОВ РАЗРЕЖЕННОЙ ДИСКРЕТИЗАЦИИ} ДЛЯ ОЦЕНКИ ХАРАКТЕРИСТИКИ КАНАЛА В СИСТЕМАХ С ОFDМ

Котляров В. В. - аспирант кафедры радиотехнических устройств и систем Национального технического университета Украины «Киевский политехнический институт им. Игоря Сикорского», Киев, Украина. 
Шпилька О. О. - канд. техн. наук, доцент кафедры радиотехнических устройств и систем Национального технического университета Украины «Киевский политехнический университет», Киев, Украина.

\section{АННОТАЦИЯ}

Актуальность. Для получения информации о состоянии канала в системах на основе ортогонального частотного разделения (OFDM) традиционно используется большое количество пилотных несущих. Увеличение количества пилотных несущих улучшает оценку состояния канала, но приводит к снижению спектральной эффективности системы.

Цель. Основная цель данной работы исследовать практические аспекты применения техники разреженной дискретизации, которая позволяет оценивать канальную характеристику по небольшому количеству пилотных несущих, в контексте реальных OFDM систем.

Метод. Современная технология разреженной дискретизации (CS) предлагает восстанавливать сигналы, которые имеют разреженное представление в некотором базисе, путем минимизации $L$ нормы, что позволяет использовать меньшее количество выборок чем требуют классические методы. Используя разреженную природу импульсной характеристики многолучевых каналов, мы применили технику разреженной дискретизации для оценки канала в системах OFDM c пилотными несущими на примере стандарта ISDB-T.

Результаты. В данной работе сравниваются результаты оценки канала для двух самых популярных алгоритмов восстановления на основе CS-Orthogonal Matching Pursuit (OMP) и Compressive Sampling Matching Pursuit (CoSaMP). Приведены показатели среднеквадратичной ошибки (MSE) для алгоритмов оценки канала на основе CS. Результаты моделирования показывают, что CoSaMP обеспечивает более стабильные результаты, но для получения хорошего качества оценки требует больше пилотных несущих, чем ОМР. Оба алгоритма требуют априорного знания степени разреженности канальной характеристики, но CoSaMP гораздо более чувствителен к правильности этой информации.

Выводы. Метод разреженной дискретизации показывает впечатляющую способность восстановления импульсной характеристики канала по значительно меньшему количеству пилотных несущих, чем требуют традиционные линейные методы. Однако потребность популярных CS методов восстановления в априорном знании степени разреженности характеристики серьезно ограничивает применимость этих алгоритмов в реальных приемниках OFDM. Тем не менее, оценка канала на основе CS является многообещающим методом, который заслуживает дальнейшего изучения с целью устранения данного ограничения.

КЛЮЧЕВЫЕ СЛОВА: ОFDM, многолучевой канал, оценка характеристики канала, разреженная дискретизация.

\section{ЛІТЕРАТУРА / ЛИТЕРАТУРА}

1. Proakis J.G. Digital communications 4ed. / J. G. Proakis. New York : McGraw-Hill, 1983. - 1002 p.

2. On Channel Estimation in OFDM Systems / [J-J. van de Beek, O. Edfors, M. Sandell, et al.] // Vehicular Technology: 45th international conference, Chicago, 25-28 july 1995: proceedings. - Chicago : IEEE, 1995. - Vol. 2. P. 815-819. DOI: 10.1109/VETEC.1995.504981

3. Li Y. Pilot-Symbol-Aided Channel Estimation for OFDM in Wireless Systems / Y. Li // IEEE Transactions on Vehicular Technology. - 2000. - Vol. 49, Issue 4. P. 1207-1215. DOI: $10.1109 / 25.875230$

4. Wang X. Modified Channel Estimation Algorithms for OFDM Systems with Reduced Complexity / X. Wang, Y. Wu, J. Y. Chouinard // Signal processing: 7th international conference, Beijing, 31 august -4 september 2004: proceedings. - Beijing : IEEE, 2004. - Vol. 2. P. 1747-1751. DOI: 10.1109/ICOSP.2004.1452558

5. Khan M. Z. Low-Complexity ML Channel Estimation Schemes for OFDM / M. Z. Khan // Conference on networks: 13th international conference, Kuala Lumpur, 16-18 november 2005: proceedings. - Kuala Lumpur: IEEE, 2005. - Vol. 2. - P. 607-612. DOI: 10.1109/ICON.2005.1635572

6. Zhou Y. Experimental study of MIMO channel statistics and capacity via the virtual channel representation [Electronic resource] / Y. Zhou, M. Herdin, A. M. Sayeed, E. Bonek. - Access mode: https://pdfs.semanticscholar.org/266c/3a3e8228381a9335df 7d868ba5d0d2803c38.pdf

7. Donoho D.L Compressed sensing / D. L. Donoho // IEEE Transactions on Information Theory. - 2006. - Vol. 52, № 4. - P. 1289-1306. DOI: 10.1109/TIT.2006.871582

8. Candes E. J. An Introduction To Compressive Sampling / E. J. Candes, M. B. Wakin // IEEE Signal Processing
Magazine. - 2008. - Vol. 25, Issue 2. - P. 21-30 DOI: 10.1109/MSP.2007.914731

9. Baraniuk R.G. Compressive Sensing[Lectures Notes] / R. G. Baraniuk // IEEE Signal Processing Magazine. 2007. - Vol. 24, Issue 4. - P. 118-121. DOI: 10.1109/MSP.2007.4286571

10. Application of compressive sensing to sparse channel estimation / [C. R. Berger, Z. H. Wang, J. Z. Huang, et al.] // IEEE Communication Magazine. - 2010. - Vol. 48, Issue 11. - P. 164-174. DOI: 10.1109/MCOM.2010.5621984

11. Cotter S. F. Sparse channel estimation via matching pursuit with application to equalization / S. F. Cotter, B. D. Rao // IEEE Transaction on Communication. - 2002. - Vol. 50, Issue 3. - P. 374-377. DOI: 10.1109/26.990897

12. Implementation of greedy algorithms for LTE sparse channel estimation / [P. Maechler, P. Greisen, B. Sporrer et al.] // Conference Signals, System and Computers: 44th Asilomar Conference, Pacific Grove, 7-10 November 2010: proceedings - Pacific Grove: IEEE, 2010. - P. 400405. DOI: 10.1109/ACSSC.2010.5757587

13. Tropp J. A. Signal recovery from random measurements via orthogonal matching pursuit / J. A. Tropp, A. C. Gilbert // IEEE Transactions of Information Theory. - 2007. Vol. 53, Issue 12. - P. 4655-4666. DOI: 10.1109/TIT.2007.909108

14. Needell D. CoSaMP: Iterative signal recovery from incomplete and inaccurate samples / D. Needell, J. A. Tropp // Applied and Computational Harmonic Analysis. - 2009. - Vol. 26, Issue 3. - P. 301-321. DOI: 10.1016/j.acha.2008.07.002

15. Transmission System for Digital Terrestrial Television Broadcast: standard v. 2.2. [Effective from 18 March 2014]. - ARIB, 2014. - 195 p.

16. Universal mobile telecommunications systems; Deployment aspects: technical report: 3GPP TR 25.943 v14.0.0/ ETSI. - 2017, 15 p. 